\title{
EFFORTS TO CONTROL TAPIN RIVER POLLUTION IN TAPIN DISTRICT, SOUTH KALIMANTAN OF INDONESIA
}

\author{
Noor Anna*, Emmy Sri Mahreda, Kissinger, Syarifuddin Kadir \\ Postgraduate Program of Natural Resources and Environmental Management, \\ University of Lambung Mangkurat, Banjarbaru, Indonesia \\ *E-mail: nooranna.hc03@gmail.com
}

\begin{abstract}
Watershed Management (DAS) is one aspect of Water Resources Management (PSDA) in Water Resources Development (WPSA), which seeks to utilize water resources as a whole and seeks to control and protect water resources. Watershed management cannot be separated from several problems, including the depletion of natural resources, pollution from various sources, and land-use conflicts around the watershed. Intensive use or development of natural resources will worsen the condition of the watershed. Tapin Regency is one of the largest watersheds in South Kalimantan. 3 rivers are flowing in the Tapin area: Tapin River, Nagara River, and Binon River. There are two main parts to this survey. The first part is a case study conducted around the watershed to describe the relationship between watershed problems and the condition of the community around the watershed. The second part describes watersheds related to community management and behavior, based on various publications, especially those that treat watershed management as one watershed. Based on the results of the study that waste, liquid waste, knowledge and community actions in maintaining river cleanliness had a significant $91.9 \%$ effect on Tapin river pollution in Tapin Regency, South Kalimantan Province. The river management strategy to reduce the pollution of the Tapin River that can be done is by improving community actions so as not to litter and increasing public knowledge about good and correct waste management.
\end{abstract}

\section{KEY WORDS}

Watershed management, waste, liquid waste, waste management.

Water is one of the environmental components that has suffered severe damage due to pollution, so it is used as an indicator of the environmental status of a region and nationally (Yuliastuti, Sasongko, and Nugraha 2011). As one of the natural resources that support human life, rivers play an important strategic role. The role of rivers in the urban environment is very important, especially in preserving water resources. Watershed Management (DAS) is one aspect of Water Resources Management (PSDA) in Water Resources Development (WPSA), which seeks to utilize water resources as a whole and seeks to control and protect water resources.

Watershed management cannot be separated from several problems, including the depletion of natural resources, pollution from various sources and land-use conflicts around the watershed. Intensive use or development of natural resources will worsen the condition of the watershed. In recent years, water pollution remains a serious problem worldwide, which can threaten the resilience of urban systems (Mishra et al. 2017). The use of resources for development always means pollution. If the environment can be attacked by pollutants or disturbed by pollution, it can be described as polluted. Attacking creatures (Soemarwoto, 2019). For example, river pollution can be caused by high erosion, the rapid growth of organic compounds in human, animal, and plant waste, and industrial waste disposal. Rivers are a useful source of surface water for live mankind. Water flowing from source to downstream along different river channels is dynamic. This depends on the dynamics, seasons, land use, and lifestyle of the surrounding community (Hendawan 2010). In addition, what causes river pollution is the behavior of residents who inhabit along the riverbanks by throwing garbage into the river. 
Waste is defined as solid, unused, unnecessary and discarded goods. Many of us still treat waste as a daily necessity and throw it everywhere (Yunik'ati et al. 2019). Not infrequently we see road users who carelessly throw garbage in front of goods without feeling uncomfortable. On one side of the road, we see piles of garbage that are scattered and resemble small mountains. Landfills of various types can also be seen in the ditches, which have public health implications and causes slums. previously (Sholihah, Normaladewi, and Laksono 2019) said solid waste is a type of waste produced by the community and people usually call it garbage. Garbage and the environment are just a small part of the things or things that are considered unusable, unused, unwanted, or should be treated the same way. In order not to affect survival (Rhofita and AW 2019)

Based on the results of observations and documentation Tapin Regency is one of the largest watersheds in South Kalimantan. 3 rivers are flowing in the Tapin area: Tapin River, Nagara River, and Binuang River. Tapin Regency has an area of 2,174.95 square kilometers. Most of the Tapin Regency is dominated by residential areas, mainly located on the Tapin River. The Tapin River itself flows into 5 sub-districts, namely: Piani District, Bungur District, North Tapin District, Bakarangan District, and South Kandy Laras District. The Tapin River will be slightly polluted in 2020.

The river upstream of the Tapin River is one of the areas for active mining activities. Liquid waste from coal mining is discharged into the Tapin River. There are many houses by the river and 490 families doing some social activities. River water is used for bathing, washing, and cleaning. Some people do not know how to keep rivers clean, because of the large amount of plastic waste, baby diaper waste, animal food waste, agricultural and plantation waste, household waste, etc. This waste will disrupt, the balance of the ecosystem and the river environment and will harm the work of fishermen. These community groups have a negative impact because the fish caught can no longer meet their daily needs, there are even some fish that were rarely found, such as shrimp. Changes in people's consumption behavior stem from population growth and the pace of urban development. Household, agricultural and industrial activities will inevitably cause pollution that affects the quality of the river. Several factors that affect river water pollution are garbage, waste, knowledge and community actions. This is following the monitoring of the Ministry of Environment of the Republic of Indonesia (LH RI) in 2020, as many as $75 \%$ of rivers in Indonesia are heavily polluted due to waste disposal and household and industrial wastewater, lack of public knowledge, and community actions that violate government regulations in managing waste. and waste.

One of the landscape features of the area is the Barito Watershed (DAS). Of course, this will hurt the environment through the activities of the people who live in it. Most people living on the Tapin River have a toilet. Waste is discharged directly into the river, not through a sewage treatment plant. This can cause river pollution. The people of Tapin Regency who are on the banks of the Tapin River also do farming and still use environmentally friendly fertilizers. The use of environmentally friendly fertilizers can seep into rivers and pollute them. The coal mining industry that flows through the Tapin watershed also produces liquid waste that is discharged into the Tapin River.

\section{METHODS AND DISCUSSION}

There are two main parts of this survey. The first part is a case study conducted around the watershed to describe the relationship between watershed problems and the condition of the community around the watershed. The second part describes watersheds related to community management and behavior, based on various publications, especially those that treat watershed management as one watershed.

Data collection was carried out on 25 households $(\mathrm{KK})$ in each region. Data collection includes a series of indicators of overall settlement quality, population characteristics, as well as attitudes and behaviors related to the presence of rivers, covering the following aspects: a) infrastructure and housing ownership; b) physical ecological infrastructure; c) health status d) community attitudes towards rivers, e) economic conditions; and f) difficulties, fears and 
hopes related to river and flood problems. In addition, the physical condition of the entire residential area was also observed. Subsequently, a qualitative analysis was carried out on the data from the two settlements to obtain an overview of the status of the community concerning the existing physical environment of the river.

Geographical Circumstances of Tapin Regency. Regency with an area of 2,174.95 km² is one of the regencies in the province of South Kalimantan. Geographically, Tapin Regency is located between $2^{0} .32^{\prime} 43^{\prime \prime}-3^{0} .00^{\prime} 43^{\prime \prime}$ South Latitude and $114^{0} .46^{\prime} 13^{\prime \prime}-115^{0} .30^{\prime} 33^{\prime \prime}$ East Longitude, with a total population of 189,475 inhabitants.

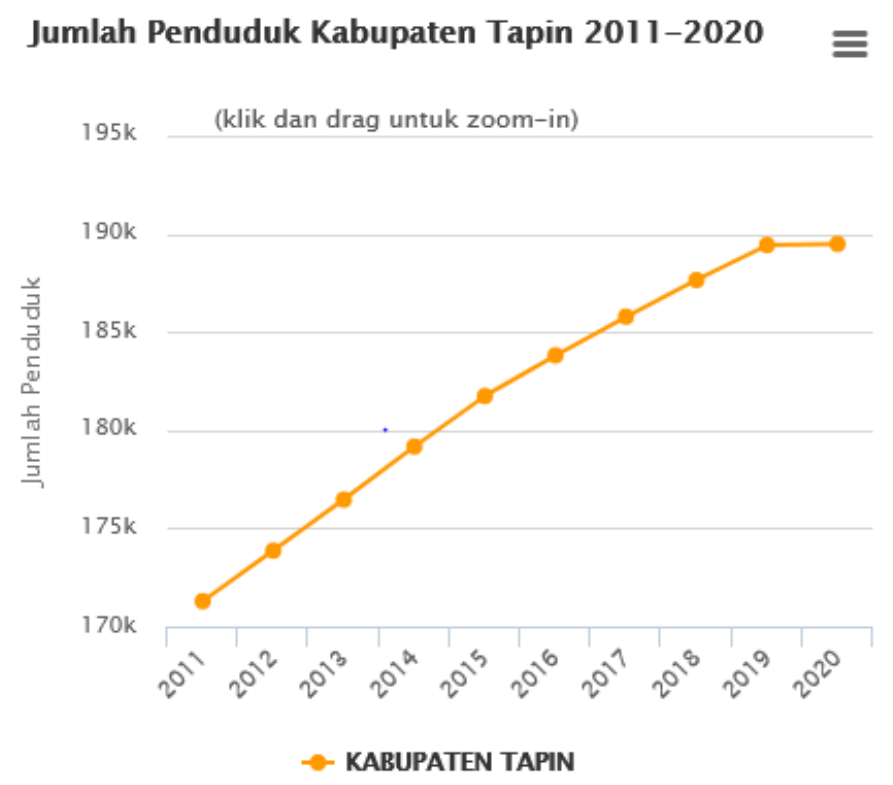

Figure 1 - Total population of Kabupaten Tapin

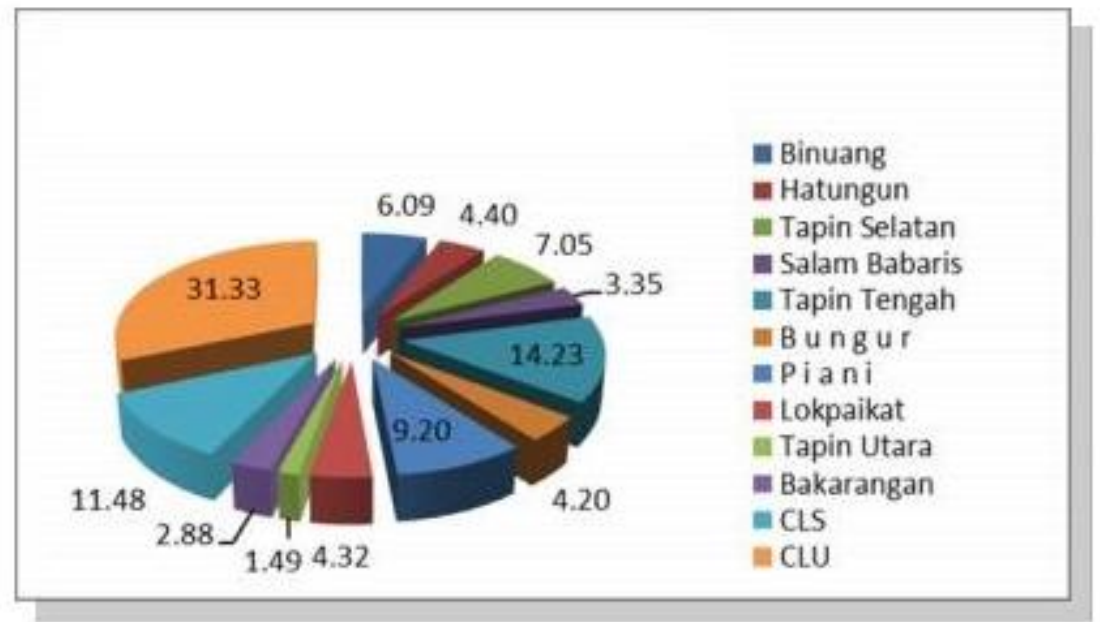

Figure 2 - Population Distribution Data 2020

Geologically, Tapin Regency consists of highlands and mountains that extend from east to south. From north to the west is mostly lowland (swamp). The most important rock types in the Tapin area are Quaternary rocks. Usually, this is the area around $80.01 \%$. Apart from Quaternary rocks, a small part of the Tapin area contains rocks from the Middle Ages. The areas with these rocks are in the Binuang and Piani areas. Most of the Tapin area is located less than 500 meters above sea level. This situation means that a high factor does not hinder the development of the agricultural sector in this direction. Areas above 500 meters above sea level are only found in a small part of the Piani area. Almost all areas in Tapin Regency are flowed by small rivers and large rivers. 
A river is a part of the earth's surface which, by its nature, becomes a place for water to flow. It can be concluded that the river is part of the land that is the place where water flows from springs or rainfall. The river is divided into three parts, namely the upstream, middle, and downstream areas. Upstream is the watershed of the river bank itself. Headwaters are usually upland areas prone to erosion, the upstream substrate of sandstones and animal groups frequently encountered are rude organic matter-eating animals Coarse Particulate Organic Matter (CPOM) is like the abundance of animal shredders. The middle stream is a transitional area between the upstream and downstream rivers. The slope angle formed in the middle area tends to be smaller so that the speed of river flow, when compared to the upstream, is relatively slower (Louhi et al. 2010)

This river is a source of surface water that is beneficial to human life. Water flowing downstream along different streams is dynamic. The driving force depends on the time of year, land use, and lifestyle of the people in the area (Zhang, Jin, and Yu 2018). By the development of the river environment and human life, these conditions will cause changes in water volume and water quality (Angello, Behailu, and Tränckner 2021).

Factors Affecting Tapin River Pollution in Tapin Regency, South Kalimantan Province. The results of the regression coefficient research can be interpreted that river pollution with the variables of garbage, liquid waste, knowledge, and action is -1.974 meaning that the constant is not equal to 0 or the regression line does not pass through the central point/ point 0 . This means that before the research was carried out, there had been pollution of the Tapin river in Tapin Regency, South Kalimantan Province. A constant of -1.974 means that if there is no garbage, liquid waste, knowledge, and community actions in maintaining the cleanliness of the river or the value is 0 , then the pollution of the Tapin river in Tapin Regency, South Kalimantan Province, the value is a (constant) $=-1.974$. This means that if it is added with factors that affect pollution, the value of pollution will increase.

Based on the results of the study the effect of the variable waste, liquid waste, knowledge, and action on the pollution of the Tapin river is $95.9 \%$ and has a significant effect simultaneously on the pollution of the Tapin river where the significant value is $0.000<0.05$. This is in line with the research of Heri Setianto (Setianto and Fahritsani 2019), which states that the factors that influence river pollution are garbage, waste, knowledge and community actions in maintaining rivers.

Based on the results of the questionnaire regarding "River water changes its color which is usually clear to cloudy" it is known that the average respondent disagrees with a mean score of 1.93. The statement regarding "River water has an unpleasant smell" is known that the average respondent disagrees with a mean score of 2.14. The statement regarding "River water experiences a change in taste, which usually tastes fresh to salty, sometimes becomes deaf in the throat." It is known that the average respondent disagrees with a mean score of 1.92. The statement regarding "It is often found that fish or aquatic biota die suddenly for no apparent reason and some species of fish are hard to find. (PH is not neutral)" is known that the average respondent disagrees with a mean score of 1.94. The statement regarding "There is sediment such as garbage and food scraps in the river" is known that the average respondent disagrees with a mean score of 2.05 . The statement regarding "There are deposits from residual fertilizers, oil and oil spills" is known that the average respondent disagrees with a mean score of 2.01. In the statement regarding "Many drinks of water, hyacinth thrives in the river" it is known that the average respondent disagrees with a mean score of 2.02.

Most people still consider this river as the last dumping ground, especially for people living on the banks of the Tapin River who are accustomed to throwing liquid waste in the river and using the river as a toilet. Community actions will also have an impact on river water pollution. The behavior of people living on the banks of the Tapin River is influenced by beliefs based on knowledge or experience about the positive values of PHBS and cleanliness. Waste management is the weakest form of behavior because the knowledge gained about the protection of water resources and good waste management cannot be applied. 
The test results on X1 (garbage) show a count of 5.401 with a significance level of 0.000 , meaning that waste has a very significant effect on river pollution. This is because based on the results of field observations, most of the people along the Tapin river throw their garbage into the river, both organic and inorganic waste. And if they don't throw it into the river, they burn the garbage. The waste variable regression coefficient of 0.371 is positive, meaning that between waste and river pollution there is a positive relationship or a straight relationship, if there is an increase in the volume of waste by 1 kilo it will result in river pollution of $0.371 \mathrm{~kg}$. This is because the data on the coverage of garbage service is still low, there is a lack of trash cans and there are still many who throw garbage carelessly. In addition, people's perceptions of garbage are still low, and throwing garbage in rivers for people who live on riverbanks has become a culture that is difficult to eliminate. The existence of local regulations regarding the prohibition of throwing garbage has also not been strictly enforced, only in the form of an appeal board, so that people still throw garbage into the river.

The test results on liquid waste (X2) show a count of 2.684 with a significance level of 0.009 , meaning that liquid waste has a very significant effect on river pollution. This is because the water quality of the Tapin river from upstream to downstream is light to moderately polluted and the disposal of household waste without treatment, the drainage, and sanitation systems are still integrated, the management of waste management is not good, such as public toilets whose waste is directly channeled into the river. The liquid waste variable regression coefficient of 0.172 is positive, meaning that between liquid waste and river pollution there is a positive relationship or a straight relationship, if there is an increase in the volume of liquid waste by 1 liter it will result in river pollution of 0.371 liters. This is because household waste that accumulates continuously has the potential to pollute the river environment. The main sources of household pollution include housing, trade, and recreation. Mining industry waste that is not managed properly also affects river pollution, as well as seepage waste from agricultural and plantation fertilization activity that use chemical fertilizers which affect river pollution. The liquid waste results in a decrease in river quality with piles of waste originating from households, industry, and agriculture.

The Effect of Knowledge and Community Actions in Maintaining River Cleanliness on Tapin River Pollution in Tapin Regency, South Kalimantan Province. The test results on knowledge in maintaining river cleanliness (X3) show a count of 4.197 with a significance level of 0.009 meaning that knowledge in maintaining river cleanliness has a very significant effect on River pollution. This is because most of the knowledge about waste and liquid waste is good. But this river pollution is constrained by the lack of self-awareness to dispose of waste and liquid waste in its place. The regression coefficient of the knowledge variable in maintaining river cleanliness is 0.339 which is positive, meaning that knowledge in maintaining river cleanliness and river pollution has a positive relationship or a straight relationship if there is an increase in the volume of knowledge in maintaining river cleanliness by 1 time it will result in river pollution. by 0.371 times. This is due to the low level of public knowledge in the management of waste and liquid waste and the lack of self-awareness to dispose of waste and liquid waste in its place and the lack of attention from all parties regarding the sustainability of the river environment.

The results of the test on knowledge in maintaining river cleanliness (X3) show a count of 4.197 with a significance level of 0.009 , meaning that knowledge in maintaining river cleanliness has a very significant effect on river pollution. This is because most of the knowledge about waste and liquid waste is good. But this river pollution is constrained by the lack of self-awareness to dispose of waste and liquid waste in its place. The regression coefficient of the knowledge variable in maintaining river cleanliness is 0.339 which is positive, meaning that knowledge in maintaining river cleanliness and river pollution has a positive relationship or a straight relationship if there is an increase in the volume of knowledge in maintaining river cleanliness by 1 time it will result in river pollution. by 0.371 times. This is due to the low level of public knowledge in the management of waste and liquid waste and the lack of self-awareness to dispose of waste and liquid waste in its place and the lack of attention from all parties regarding the sustainability of the river environment. 
River Management Strategy to Reduce Tapin River Pollution. Actions as Strengths (S) this is because if the community's actions in behavior are improved by being given the right direction and examples and these actions are also carried out as a preventive effort in reducing environmental pollution, the quality of Tapin river water will improve. This is in line with what was stated by the Head of the Tapin Regency Environmental Service and the Head of Pollution and Environmental Damage Control, who stated that every year water quality monitoring is still carried out which is usually carried out by a team from the Environmental Service, then reported to the Center and if the results are obtained unsatisfactory, immediate action will be taken with neutralization or strategies to improve the quality of the river water, because if left unchecked, the level of river pollution is feared to damage the ecosystem and can even cause various kinds of diseases for the community.

In addition, the creation of green open space (RTH) has also been carried out, but according to observations it is still not running according to the expectations and desired goals. This is following statements from several sources as follows:

Head of the Tapin Regency Environmental Service, Head of Pollution Control and Environmental Damage, Head of Water Resources, and Head of BPBD Kab. Tapin stated that until now green open space, has been managed properly and can be enjoyed by the surrounding community with the hope of improving the condition of the river border so that it does not look slum, of course, with the hope that the whole community can maintain and preserve plants and plants such as planting trees and planting mangrove trees to be able to maintain the quality of river water properly.

In principle, there are 2 (two) efforts to tackle pollution, namely non-technically and technically. Non-technical countermeasures through an effort to reduce environmental pollution by creating laws and regulations that can plan, regulate and supervise all forms of industrial and technological activities so that pollution does not occur. These laws and regulations should be able to provide a clear description of the industrial activities to be carried out, for example including Environmental Impact Analysis (AMDAL), regulation and supervision of activities, and inculcating disciplinary behavior. Meanwhile, technical countermeasures are based on proper handling of waste, including industrial treatment of its waste materials, for example by changing processes, managing waste, or adding tools that can reduce pollution to the environment.

Community Actions in Maintaining River Cleanliness is an attitude that does not automatically manifest in an action (overt behavior) because several factors are needed such as facilities and support factors from other parties to make it a real action, in this case of course support from the Government, The Environment Agency and other related agencies to improve the quality of the Tapin River so that it is not polluted. Actions have several levels, namely by recognizing and selecting various objects in connection with the actions to be taken, such as regarding waste and waste management, community actions to plant trees, community actions so as not to throw garbage and waste into rivers, community actions willing to take clean-up actions. the river with the community and willing to cooperate with the government in maintaining the cleanliness of the river.

Efforts to overcome waste pollution such as increasing the scope of waste services, socialization, and strictly implementing Regional Regulation no. 06 of 2015 concerning Waste Management, a comprehensive approach for overcoming river pollution by garbage, to maintain a good quality of the aquatic environment. The government should also issue a policy to manage waste with a $3 \mathrm{R}$ approach (Reduce, Reuse and Recycle) and need continuous socialization continuously to the public about the importance of maintaining water quality from waste pollution.

\section{CONCLUSION}

Garbage, liquid waste, knowledge and community actions in maintaining the cleanliness of the river have a significant effect of $91.9 \%$ on the pollution of the Tapin river in Tapin Regency, South Kalimantan Province. 


\section{REFERENCES}

1. Angello, Zelalem Abera, Beshah M. Behailu, and Jens Tränckner. 2021. "Selection of Optimum Pollution Load Reduction and Water Quality Improvement Approaches Using Scenario Basedwater Quality Modeling in Little Akaki River, Ethiopia." Water (Switzerland) 13(5): 584. https://www.mdpi.com/2073-4441/13/5/584/htm (July 8, 2021).

2. "Badan Pusat Statistik Kabupaten Tapin." https://tapinkab.bps.go.id/ (August 4, 2021).

3. Hendrawan, Diana. 2010. "Kualitas Air Sungai Dan Situ Di Dki Jakarta." Makara of Technology Series.

4. Louhi, Katja Riikka, Anssi Karvonen, Christian Rellstab, and Jukka Jokela. 2010. "Is the Population Genetic Structure of Complex Life Cycle Parasites Determined by the Geographic Range of the Most Motile Host?" Infection, Genetics and Evolution 10(8): 1271-77.

5. Mishra, Binaya K. et al. 2017. "Assessment of Bagmati River Pollution in Kathmandu Valley: Scenario-Based Modeling and Analysis for Sustainable Urban Development." Sustainability of Water Quality and Ecology 9-10: 67-77.

6. Rhofita, Erry Ika, and Liliek Chana AW. 2019. "Pemanfaatan Limbah Jerami Padi Di Desa Garon Kecamatan Balerejo, Kabupaten Madiun." Jurnal Inovasi Hasil Pengabdian $\begin{array}{lll}\text { Masyarakat } & \text { (JIPEMAS) } & \text { 120-31. }\end{array}$ http://riset.unisma.ac.id/index.php/jipemas/article/view/2915 (August 4, 2021).

7. Setianto, Heri, and Husni Fahritsani. 2019. "Faktor Determinan Yang Berpengaruh Terhadap Pencemaran Sungai Musi Kota Palembang." Media Komunikasi Geografi 20(2): 186. https://ejournal.undiksha.ac.id/index.php/MKG/article/view/21151.

8. Sholihah, Fitri Awaliyatush, Andi Normaladewi, and Prayitno Tri Laksono. 2019. "Pengolahan Plastik Bekas Menjadi Bantal Hias Di Desa Ngempit Kecamatan Kraton Kabupaten Pasuruan." Jurnal Inovasi Hasil Pengabdian Masyarakat (JIPEMAS) 2(1): 917. http://www.riset.unisma.ac.id/index.php/jipemas/article/view/1640 (August 4, 2021).

9. Soemarwoto, Otto. 2019. "Analisis Mengenai Dampak Lingkungan." Sustainability (Switzerland) 11(1): 1-14. http://scioteca.caf.com/bitstream/handle/123456789/1091/RED2017-Eng-

8ene.pdf?sequence=12\&isAllowed=y\%0Ahttp://dx.doi.org/10.1016/j.regsciurbeco.2008.0 6.005\%0Ahttps://www.researchgate.net/publication/305320484_sistem_pembetungan_te rpusat_strategi_melestari (July 8, 2021).

10. Yuliastuti, Etik, Setia Budi Sasongko, and Winardi Dwi Nugraha. 2011. "Evaluasi Kualitas Air Sungai Ngringo Kabupaten Karanganyar Dalam Upaya Pengendalian Pencemaran Perairan." Prosiding Seminar Rekayasa dan Proses I(02): 1-6.

11. Yunik'ati, Yunik'ati, Rio Miftakhul Imam, Febri Hariyadi, and Ismi Choirotin. 2019. "Sadar Pilah Sampah Dengan Konsep 4R (Reduce, Reuse, Recycle, Replace) Di Desa Gedongarum, Kanor, Bojonegoro." Jurnal Inovasi Hasil Pengabdian Masyarakat (JIPEMAS) 2(2): 81-87. http://riset.unisma.ac.id/index.php/jipemas/article/view/1122 (August 4, 2021).

12. Zhang, Hong, Gui Jin, and Yan Yu. 2018. "Review of River Basinwater Resource Management in China." Water (Switzerland) 10(4): 425. https://www.mdpi.com/20734441/10/4/425/htm (July 8, 2021). 